\title{
Disruption of zinc transporter ZnT3 transcriptional activity and synaptic vesicular zinc in the brain of Huntington's disease transgenic mouse
}

\author{
Li Niu' ${ }^{1}$ Li Li ${ }^{2}$, Shiming Yang ${ }^{1}$, Weixi Wang ${ }^{1}$, Cuifang Ye ${ }^{1 *}$ and $\mathrm{He} \mathrm{Li}^{1,3^{*}}$
}

\begin{abstract}
Background: Huntington's disease (HD) is a neurodegenerative disease that involves a complex combination of psychiatric, cognitive and motor impairments. Synaptic dysfunction has been implicated in HD pathogenesis. However, the mechanisms have not been clearly delineated. Synaptic vesicular zinc is closely linked to modulating synaptic transmission and maintaining cognitive ability. It is significant to assess zinc homeostasis for further revealing the pathogenesis of synaptic dysfunction and cognitive impairment in HD.

Results: Histochemical staining by autometallography indicated that synaptic vesicular zinc was decreased in the hippocampus, cortex and striatum of N171-82Q HD transgenic mice. Analyses by immunohistochemistry, Western blot and RT-PCR found that the expression of zinc transporter 3 (ZnT3) required for transport of zinc into synaptic vesicles was obviously reduced in these three brain regions of the HD mice aged from 14 to 20 weeks and BHK cells expressing mutant huntingtin. Significantly, dual-luciferase reporter gene and chromatin immunoprecipitation assays demonstrated that transcription factor Sp1 could activate ZnT3 transcription via its binding to the GC boxes in ZnT3 promoter. Moreover, mutant huntingtin was found to inhibit the binding of Sp1 to the promoter of ZnT3 and down-regulate ZnT3 expression, and the decline in ZnT3 expression could be ameliorated through overexpression of Sp1.

Conclusions: This is first study to reveal a significant loss of synaptic vesicular zinc and a decline in ZnT3 transcriptional activity in the HD transgenic mice. Our work sheds a novel mechanistic insight into pathogenesis of HD that mutant huntingtin down-regulates expression of ZnT3 through inhibiting binding of Sp1 to the promoter of ZnT3 gene, causing disruption of synaptic vesicular zinc homeostasis. Disrupted vesicular zinc ultimately leads to early synaptic dysfunction and cognitive deficits in HD. It is also suggested that maintaining normal synaptic vesicular zinc concentration is a potential therapeutic strategy for HD.
\end{abstract}

Keywords: Synaptic vesicular zinc, Zinc transporter 3, Sp1, Transcriptional inhibition, Synaptic dysfunction, Huntingtin, Huntington's disease

\footnotetext{
*Correspondence: yecf@tjmu.edu.cn; heli@tjmu.edu.cn

1 Department of Histology and Embryology, Tongji Medical College,

Huazhong University of Science and Technology, 13 \# Hangkong Road, Wuhan 430030, People's Republic of China

Full list of author information is available at the end of the article
}

\begin{abstract}
Background
Huntington's disease (HD) is an autosomal dominant neurodegenerative disease caused by the pathological expansion of CAG repeats (>36) in the first exon of the HD gene encoding huntingtin (Htt) [1-7]. Neuropathologically, the neuronal loss occurs primarily in the striatum and the
\end{abstract}

(c) The Author(s) 2020. This article is licensed under a Creative Commons Attribution 4.0 International License, which permits use, sharing, adaptation, distribution and reproduction in any medium or format, as long as you give appropriate credit to the original author(s) and the source, provide a link to the Creative Commons licence, and indicate if changes were made. The images or other third party material in this article are included in the article's Creative Commons licence, unless indicated otherwise in a credit line to the material. If material is not included in the article's Creative Commons licence and your intended use is not permitted by statutory regulation or exceeds the permitted use, you will need to obtain permission directly from the copyright holder. To view a copy of this licence, visit http://creativeco mmons.org/licenses/by/4.0/. The Creative Commons Public Domain Dedication waiver (http://creativecommons.org/publicdomain/ zero/1.0/) applies to the data made available in this article, unless otherwise stated in a credit line to the data. 
cortex in the early stages of HD. However, other brain regions, such as the hippocampus, hypothalamus, brainstem, and spinal cord, are also affected in advanced stages [1-5]. HD symptoms occur usually in mid-life, comprising movement, cognitive and psychiatric impairments inexorably progressing to death within two decades [6]. Psychiatric deteriorations and cognitive deficits precede the onset of motor disorder [5, 6], and even the onset of both psychiatric and motor symptoms often occur years prior to detectable neuronal loss [6].

Synaptic dysfunction greatly contributes to HD pathogenesis [7-9]. Neurotransmitter release significantly alters in the transgenic HD mouse models [10, 11]. Neuronal and synaptic dysfunction precedes cell death by many years in the HD patients [7, 8] and animal models [9]. Furthermore, some pharmacological interventions focus on targeting early synaptic disturbances, which has been proven to restore synaptic function [12-14] and delay progression to neurodegeneration in HD transgenic mice $[15,16]$. Therefore, disturbed synaptic function accounts for the early symptoms of HD and triggers neuronal death in later stages of the disease $[17,18]$. It is vital to investigate the mechanism of synaptic damage in HD disease.

The divalent cation zinc in the brain contributes to efficient synaptic transmission. Approximately, $85 \%$ of total brain zinc is tightly bound to metalloproteins. $10-15 \%$ of total brain zinc is highly localized in synaptic vesicles of excitatory glutamatergic neurons $[19,20]$. This pool of zinc, the ionic zinc, is either free or chelatable. It can be detected with simple histochemical method such as neo-Timm's sulfide-silver method [21, 22], and is thus often called histochemically reactive zinc. Neurons containing histochemically detectable zinc are present in many regions of the brain, including the neocortex, striatum, hippocampus, amygdale and olfactory bulb [23]. Vesicular zinc is closely linked to modulating synaptic transmission. It serves as a singal factor to play an important role in modifying glutamatergic neurons [24]. Zinc releases from glutamatergic neuron terminals, which may protect neurons from excitotoxicity of glutamate to attenuate the excess amount of presynaptic glutamate release [25]. Zinc deficiency affects neurogenesis and trigger neuronal apoptosis. Therefore, this can result in learning and memory deficits [25].

More improtantly, the homeostasis of zinc in the brain is tightly regulated. The zinc transporters (ZnTs) mainly function to efflux zinc out of cytoplasm or into intracellular organelles [26]. Among them, zinc transporter 3 (ZnT3), the primary vesicular zinc transporter, is located on the membrane of synaptic vesicles to transport zinc ions into presynaptic vesicles from the cytosol [26]. The concentration of vesicular zinc depends on the abundance of ZnT3 [26, 27]. Targeted deletion of ZnT3 gene eliminates zinc from synaptic vesicle, which leads to age-dependent deficits in learning and memory ability [27] and neurodegeneration [27, 28]. Consequently, ZnT3-dependent zinc homeostasis in synaptic vesicles takes an important role in maintaining synaptic function.

An imbalance of vesicular zinc homeostasis is associated with the pathogenesis of multiple neurodegenerative diseases, including Parkinson's disease (PD) [29], Alzheimer's disease (AD) [30] and amyotrophic lateral sclerosis (ALS) [31]. These diseases have in common with HD features and mechanisms that the misdolded proteins cause neuronal death at the late onset of the disorder. Altered homeostasis of essential elements such as iron, chromium and selenium has been observed in the HD patients [32, 33] and mice model [34]. Specially, increased level of zinc is detected in the blood of HD patients, indicating that mutant $\mathrm{Htt}$ (mHtt) might impair zinc homeostasis [32]. Nevertheless, it remains unclear whether mHtt affect zinc homeostasis in the brain. Here, we report that mHtt reduces $\mathrm{ZnT} 3$ expression by inhibiting the binding of $\mathrm{Sp} 1$ to ZnT3 promoter and down-regulates vesicular zinc level in the brain of N171-82Q HD transgenic (TG) mice. It is therefore suggested that disruption of vesicular zinc homeostasis may ultimately contribute to synaptic dysfunction and neurodegeneration in HD.

\section{Results}

\section{N171-82Q HD transgenic mice display significant loss} of total zinc and vesicular zinc in the brain tissue

The flame atomic absorption spectrometry (FAAS) and autometallography (AMG) were respectively applied to explore the effect of mHtt on total and vesicular zinc level in the brain tissue of TG mice. Comparison of the 20-week-old TG mice with age-matched wild type (WT) mice showed that total zinc level was extremely low in the cortex, striatum and hippocampus examined in the HD mice, compared to controls (Additional file 1: Figure S1).

AMG results under light microscope showed that histochemically reactive zinc was significantly decreased in all three brain regions examined in the 20-week-old TG mice, compared to controls (Fig. 1). In the wild type (WT) mice, intense AMG staining was seen in the CA1, CA2 and CA3 region of hippocampus (Fig. 1a, b), cortex (Fig. 1e) and striatum (Fig. 1e, f). However, the HD mice presented faint zinc staining in the corresponding brain regions (Fig. 1c, d, g, h).

Under electron microscope, the AMG reactive zinc granules were present within synaptic vesicles in the striatum of the WT mice (Fig. 2a), whereas the number of positive vesicles was rarely seen in the striatum of the HD mice (Fig. 2b). These collective findings indicates that zinc is unbalanced in the HD brain and suggests a role of zinc in HD pathogenesis. 

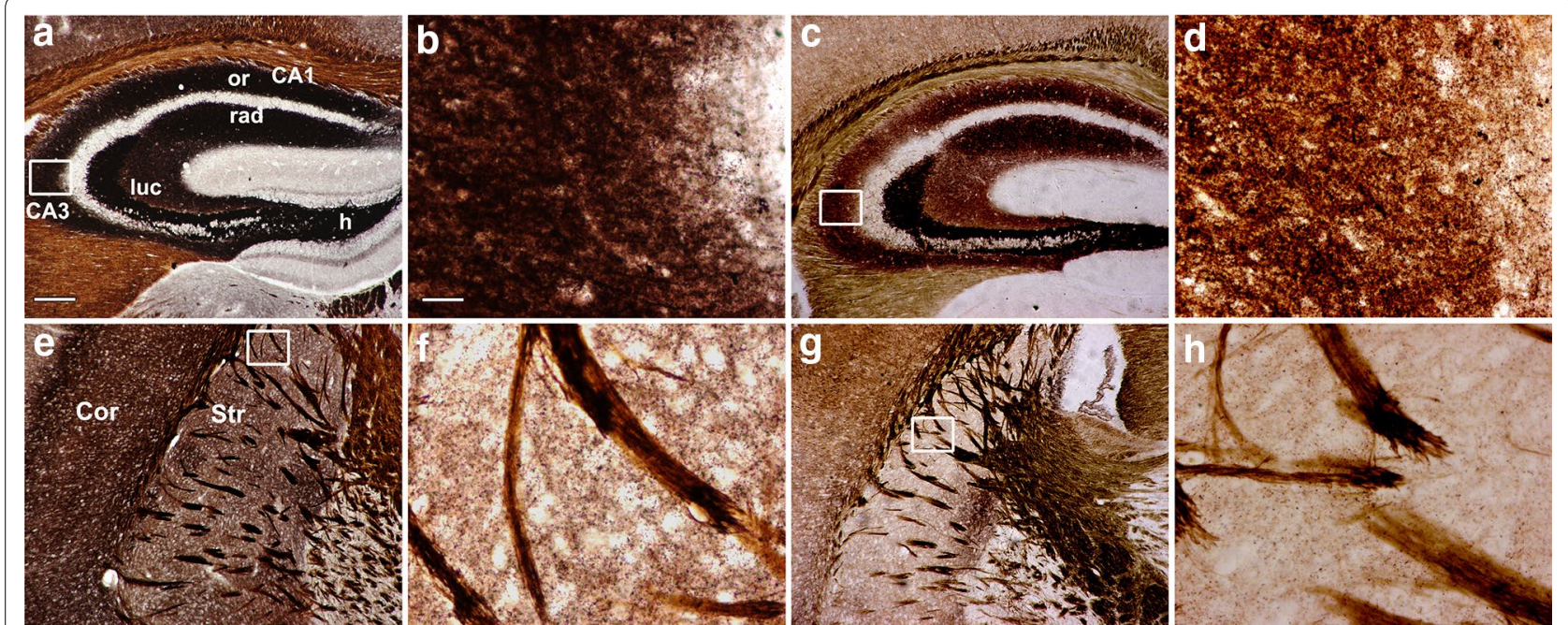

Fig. 1 Light microscopic images of vesicular zinc in TG mice brain. AMG stain is abundant in hippocampus and striatum of the 20-week-old WT mice (a, b, hippocampus; e, $\mathbf{f}$, striatum), but very week in age-matched TG mice brain (c, $\mathbf{d}$, hippocampus; $\mathbf{g}, \mathbf{h}$, striatum). $\mathbf{b}, \mathbf{d}, \mathbf{f}$ and $\mathbf{h}$ are the magnified images indicated by boxed areas in $\mathbf{a}, \mathbf{c}, \mathbf{e}$ and $\mathbf{g}$, respectively. $h$ hilus, luc s lucidum; or: s oriens; rad s radiatum, Cor cortex, Str striatum. Scale bars: $500 \mu \mathrm{m}$ in $\mathbf{a}, \mathbf{c}, \mathbf{e}$ and $\mathbf{g} ; 125 \mu \mathrm{m}$ in $\mathbf{b}, \mathbf{d}, \mathbf{f}$ and $\mathbf{h}$

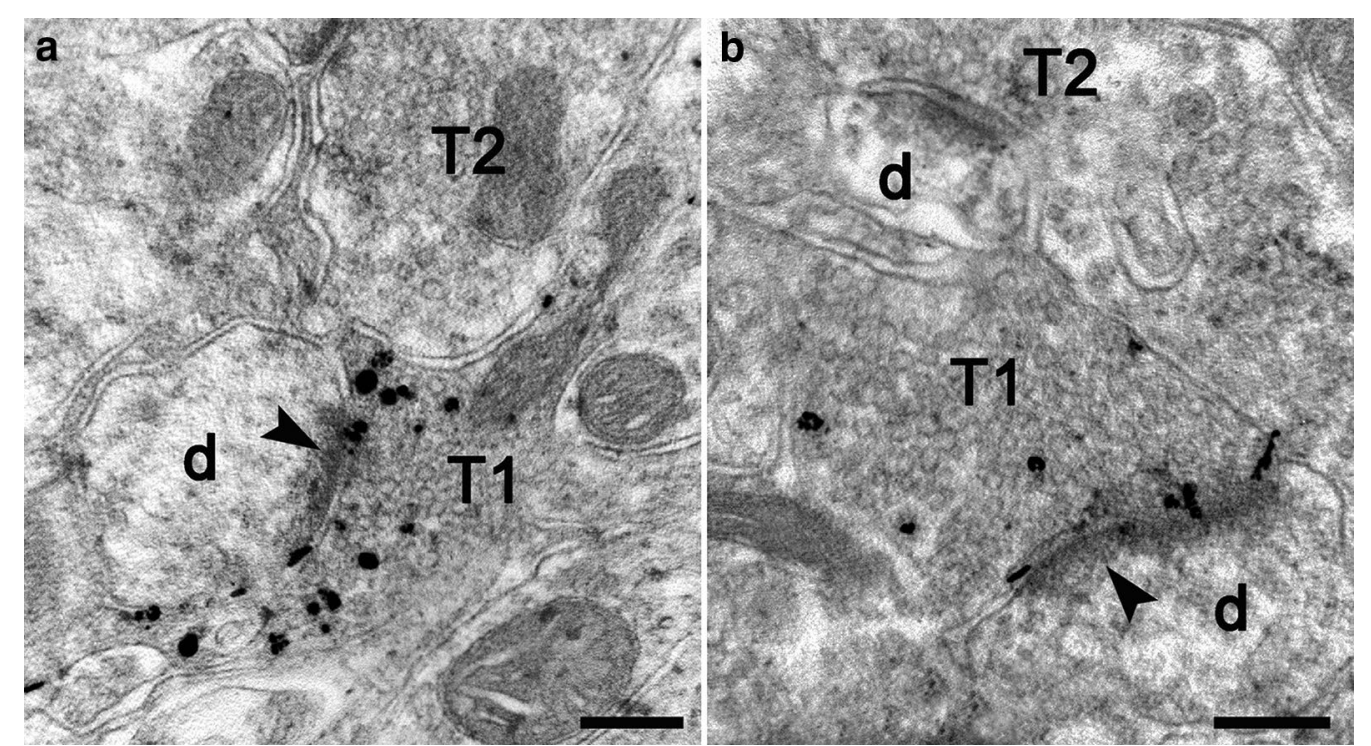

Fig. 2 Electron microscopic images of vesicular zinc in the striatum of TG mice. Zinc density in synaptic vesicles dramatically decreases in the striatum of the 20-week-old TG mice (b) compared to age-matched WT mice (a). Arrowheads show postsynaptic membrane. T1 axonal terminal containing AMG positive granules; T2 axonal terminal without AMG positive granules, $d$ dendrite. Scale bars: $0.2 \mu \mathrm{m}$

\section{ZnT3 expression is decreased in N171-82Q HD transgenic mice and BHK cells expressing mutant huntingtin}

$\mathrm{ZnT3}$ is required for transport of zinc into synaptic vesicles and the amount of ZnT3 on synaptic vesicle membranes regulates concentration of vesicular zinc [27]. To identify whether the decrease of vesicular zinc in HD brain is due to impairment of ZnT3 expression, we examined ZnT3 level in TG mice brains and BHK cells expressing $\mathrm{N}$-terminal $\mathrm{mHtt}$ containing 160 glutamine repeats (160Q cells). Light microscopic immunohistochemistry revealed that $\mathrm{ZnT3}$ immunoreactivities were intense in the hippocampus, striatum and cortex of the 20-week-old WT mice (Fig. 3a, b). In contrast, only weak 

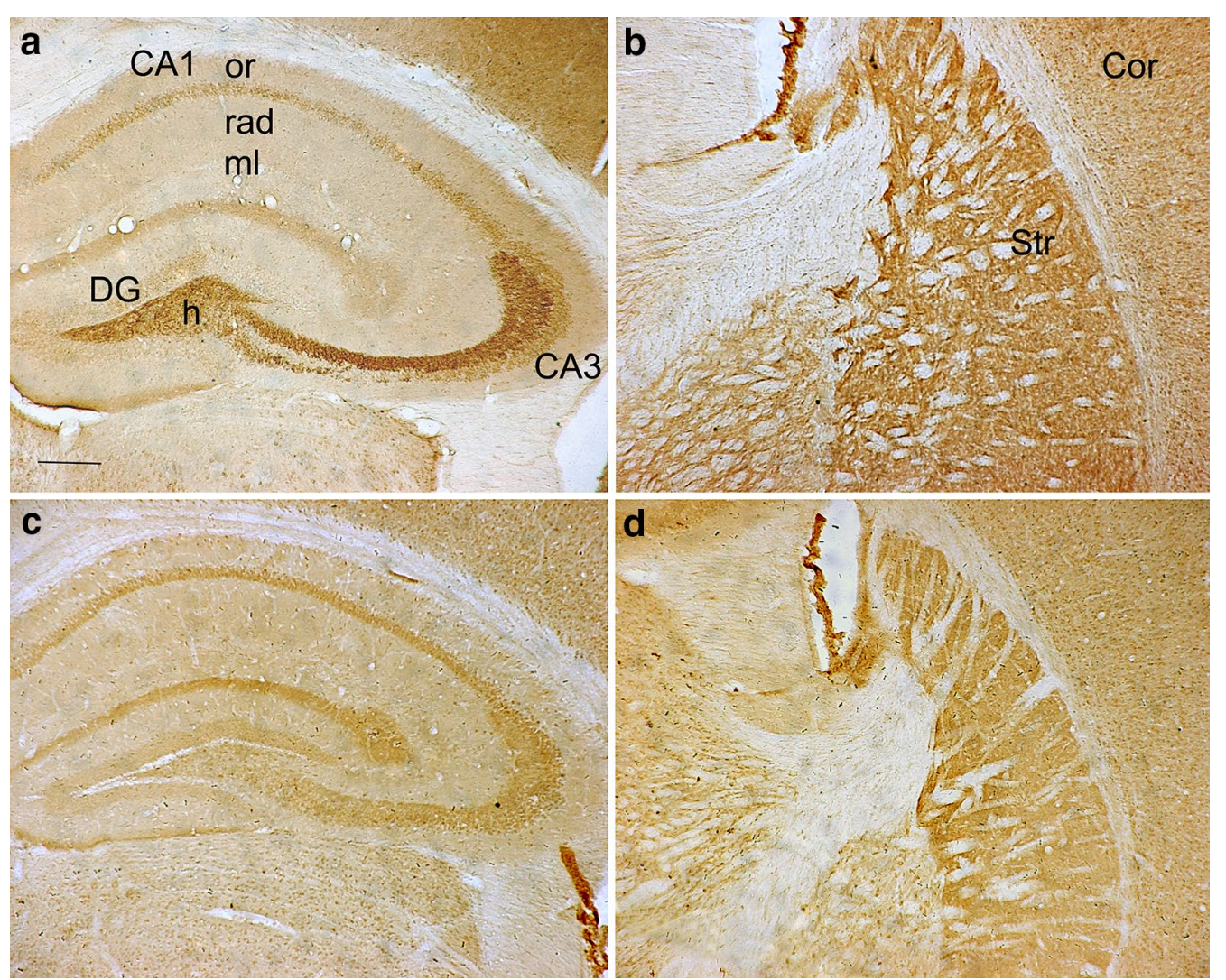

Fig. 3 Immunohistochemistry determination of ZnT3 expression in TG mice brain. The 20-week-old TG mice (c hippocampus, d striatum) display weak ZnT3-immunoreactivities in the brain, compared to age-matched WT mice (a hippocampus, b striatum). DG dentate gyrus, $\mathrm{m} / \mathrm{molecular}$ layer. Scale bar: $500 \mu \mathrm{m}$

ZnT3-immunoreactivities were seen in the same brain regions of age-matched TG mice (Fig. 3c, d).

Further, Western blot and RT-PCR analyses found that the protein and mRNA levels of ZnT3 in the cortex, hippocampus and striatum were markedly reduced in 14-, 18-, and 20-week-old TG mice in comparison with age-matched WT controls (Fig. 4a, b). In the 160Q cells, decreased protein and mRNA levels of ZnT3 were also detected by Western blot and RT-PCR (Fig. 4c, d). Therefore, it is reasonable to conclude that mHtt causes the loss of vesicular zinc by down-regulating ZnT3 expression.

\section{Sp1 positively regulates $\mathrm{ZnT} 3$ expression through activating ZnT3 promotor}

Gene transcriptional dysregulation is greatly involved in the mechanisms of neurodegeneration in HD [35]. To clarify if the down-regulation of ZnT3 expression might result from transcriptional inhibition in HD, we assessed ZnT3 promoter via bioinformatics. The data hints that the promoter of mouse $\mathrm{ZnT} 3$ gene contains two GC-rich boxes, which might be Sp1 binding sites (Fig. 5a). Sp1, a key transcription factor isolated from human being, has been shown to recognize related GC motifs within promoter regions [36]. One GC-rich box (GC-1) in ZnT3 promoter is from $-269 \mathrm{bp}$ to $-261 \mathrm{bp}$, the other (GC2 ) is from -184 bp to -174 bp (Fig. 5a). These putative Sp1 sites are conserved among human, rat, and mouse. To verify whether Sp1 is a transcription factor of ZnT3, we first examined the effect of $\mathrm{Sp} 1$ on the $\mathrm{ZnT} 3$ promoter activity by using dual-luciferase reporter gene assay. The reporter activities of pGL3-ZnT3 $(-283-+10)$ containing both GC-1 and GC-2 sequence and pGL3ZnT3 (-193-+10) containing GC-2 sequence were significantly up-regulated in Sp1 transfected cells (Fig. 5b). However, the reporter activities of pGL3-ZnT3 $(-171-+10)$ without putative Sp1 binding sites displayed no differences in Sp1 transfected cells and control cells (Fig. 5b). This finding suggests that Sp1 affects the promoter activity of ZnT3 through GC boxes.

To further demonstrate if Sp1 transactivates $\mathrm{ZnT3}$ by binding GC boxes in the promoter, we pursued chromatin immunoprecipitation (ChIP) assay. Sp1 antibody precipitated more DNAs containing these $\mathrm{ZnT3}$ promoter sequences with GC-1 or GC-2 than a mock 
a

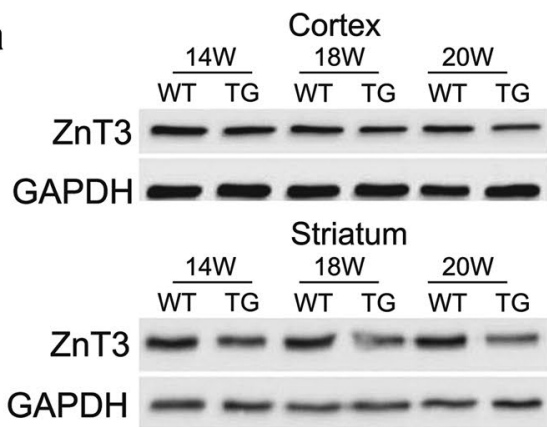

Hippocampus

$\frac{14 \mathrm{~W}}{\mathrm{WT} \quad \mathrm{TG}} \frac{18 \mathrm{~W}}{\mathrm{WT}} \frac{20 \mathrm{~W}}{\mathrm{WT}}$
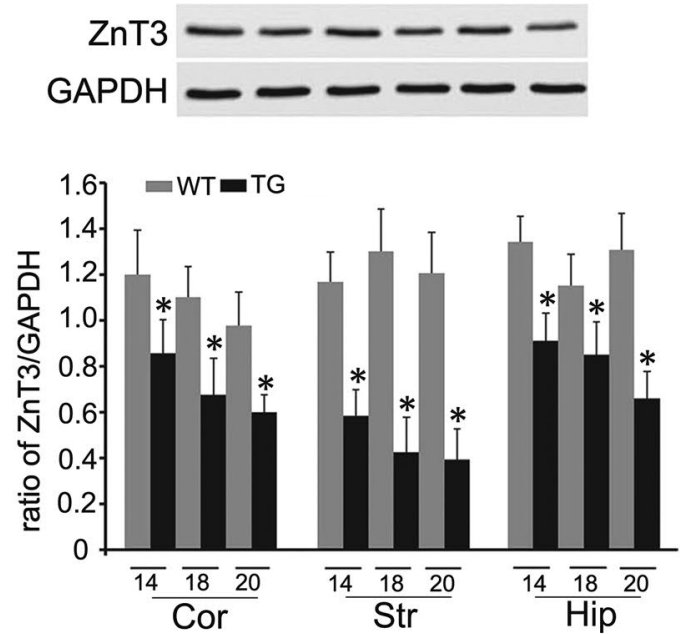

C
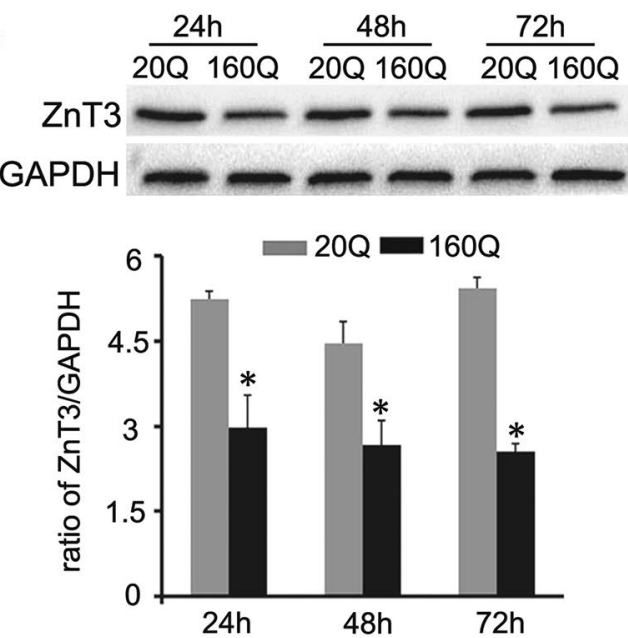

b

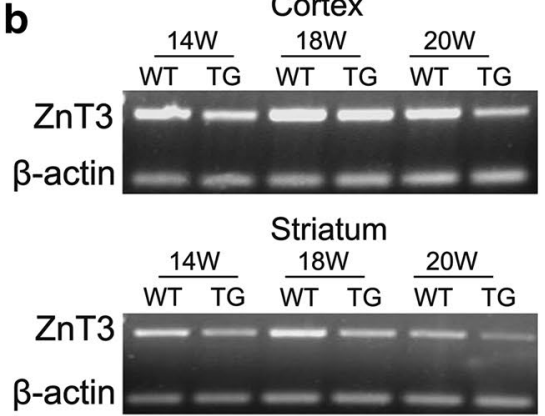

Hippocampus
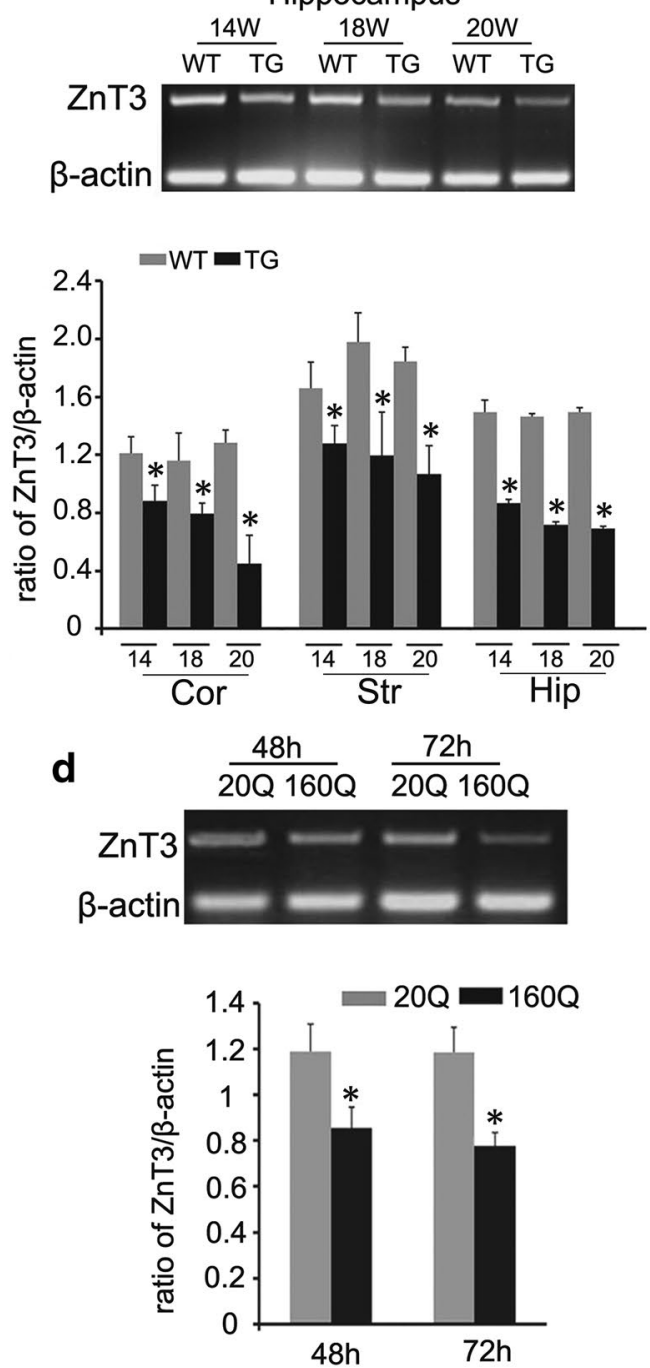

Fig. 4 Mutant huntingtin impairs ZnT3 protein and mRNA expression. $\mathbf{a}$, b The expression of ZnT3 is decreased in cortex, striatum and hippocampus of TG mice aged from 14 to 20 weeks, compared to age-matched WT mice (a Western blot analysis, b RT-PCR analysis). Hip hippocampus. $n=4 .{ }^{*} p<0.05$ compared to WT mice. $\mathbf{c}$, $\mathbf{d}$ The expression of ZnT3 is decreased in $160 \mathrm{Q}$ BHK cells at different times after transfection, compared to 20Q BHK cells (c Western blot analysis, $\mathbf{d}$ RT-PCR analysis). $n=4 .{ }^{*} p<0.05$ compared to $20 \mathrm{Q}$ BHK cells

immunoprecipitation with control IgG (Fig. 5c). Additionally, Sp1 overexpression significantly promoted the expression of endogenous ZnT3 protein and mRNA in
WT BHK cells (Fig. 5d, e and Additional file 1: Figure S2). In contrast, knockdown of Sp1 resulted in a decline in ZnT3 protein and mRNA levels (Fig. 5f, g and Additional 
file 1: Figure S3). Consequently, these results imply that $\mathrm{Sp} 1$ plays a key role in transcriptional regulation of $\mathrm{ZnT} 3$ gene.

\section{Mutant huntingtin disturbs ZnT3 transcription by inhibiting the binding of Sp1 to $\mathrm{ZnT3}$ promoter}

We further investigated the effect of mHtt on ZnT3 transcription activity. Different concentrations of $\mathrm{mHtt}$ vector $(0.5 \mu \mathrm{g}, 1 \mu \mathrm{g}, 2 \mu \mathrm{g})$ were respectively co-transfected with reporter plasmid pGL3-ZnT3 $(-283-+10)$ into BHK cells. Dual-luciferase reporter gene assay showed that $160 \mathrm{Q} \mathrm{Htt}$ reduced the ZnT3 promoter activity, compared to 20Q Htt (Fig. 6a).

Mutant huntingtin has been demonstrated to inhibit the binding of Sp1 to target genes in HD [35, 36]. In this report, ChIP assay displayed that there was a significant decrease in Sp1-immunoprecipitated DNA consisting of ZnT3 promoter in 160Q cells, compared to 20Q cells (Fig. 6c). However, overexpression of Sp1 ameliorated ZnT3 promoter activity (Fig. 6b) and up-regulated ZnT3 mRNA level in 160Q cells (Fig. 6d). In summary, these data indicate that mHtt disturbs $\mathrm{ZnT} 3$ transcription by inhibiting the binding of Sp1 to ZnT3 promoter, and Sp1 reverses the suppression of $\mathrm{mHtt}$ to $\mathrm{ZnT} 3$ transcription activity.

\section{Discussion}

Impairment of synaptic function contributes to the HD pathogenesis. Vesicular zinc is of significance for synaptic function. Herein, we identified a significant loss of total zinc, especially vesicular zinc in the brain of the HD transgenic mice. Furthermore, a reduction of ZnT3 expression was observed in these mice and 160Q BHK cells. ZnT3, an important protein located on the membrane of synaptic vesicles, affects synaptic function via various mechanisms in neurons [28]. Most important of all, ZnT3 is responsible for the movement of zinc from the cytoplasm to the synaptic vesicles. Vesicular zinc level is dependent on ZnT3 protein abundance. Zinc is eliminated from synaptic vesicles in the brain of ZnT3 knockout mice [27]. In the present study, we found that vesicular zinc detected by AMG staining is dramatically decreased in the striatum, hippocampus and cortex of TG mice compared to age-matched controls, suggesting that the reduced ZnT3 expression in HD greatly disturbs zinc homeostasis in synaptic vesicles.

It is well-known that brain zinc homeostasis is strictly controlled to guarantee physiological function under healthy conditions. Vesicular zinc serves as a signal factor in a subclass of glutamatergic neurons, which is linked to glutamate signaling and cognitive activity [37, 38]. Specially, vesicular zinc can inhibit glutamate release. In mutant mice lacking vesicular zinc, glutamate release inhibition induced by zinc is absent [39]. Several lines of evidence support a key role of glutamate-mediated excitotoxic cell death in HD pathogenesis [40, 41]. Thus, it appears likely that loss of vesicular zinc in TG mice aggravates glutamate-mediated excitotoxic neuron death. On the other side, vesicular zinc signaling meets the requirement for cognitive and emotional behavior [27]. Movement impairment and cognitive deficits occur prior to neuron degeneration in HD patients [6]. Our results reveal that vesicular zinc level is lower in the hippocampus of TG mice compared to WT mice. Consequently, the decrease of vesicular zinc might be responsible for the cognitive decline in HD.

Beside affecting vesicular zinc, the reduced ZnT3 expression may also impair synaptic structures and proteins. In ZnT3 knockout mice, there is a decrease in total dendritic spines per neuron. Similarly, synaptic plasticity-related proteins, such as presynaptic synaptosomeassociated protein 25 (SNAP25) and postsynaptic PSD95, are markedly decreased in the absence of ZnT3 [27]. It has been reported that both SNAP25 and PSD95 are also defective in HD $[42,43]$. Of note is that TG mice showed significant reductions in $\mathrm{ZnT} 3$ protein and mRNA levels at a relatively early stage of this disease (about 14 weeks). Subtle alterations in synaptic function can lead to the early symptoms of HD [44]. In consequence, we conclude that reduction of $\mathrm{ZnT} 3$ expression in the HD brain may result in synaptic dysfunction.

One of distinctive characteristics of mHtt is to form aggregates or inclusions, which directly recruit synaptic proteins $[45,46]$. To understand how mHtt causes the reduction of $\mathrm{ZnT} 3$ expression in $\mathrm{HD}$, subsequently, we first examined whether mHtt aggregates could recruit ZnT3 protein. Co-immunoprecipitation results showed that ZnT3 protein was not detected in aggregates,

(See figure on next page.)

Fig. 5 Sp1 up-regulates ZnT3 gene transcriptional activity. a The scheme chart of the mouse ZnT3 promoter sequence. Potential Sp1 binding sites (GC-1 and GC-2) are underlined. b Dual-luciferase (Luc) report gene assay of the targeting relationship of Sp1 and ZnT3. Sp1 activates ZnT3 transcription by binding to GC boxes in ZnT3 promoter. $n=3 * p<0.05$ compared to BHK cells transfected with empty pEBGN vector. (C) ChIP analysis of Sp1 binding to ZnT3 promoter. The relative amounts of ZnT3 promoter were normalized to input DNA. GC-1: ZnT3 promoter (-338 to -232$)$; GC-2:ZnT3 promoter ( -253 to -112$)$. n=3. ${ }^{*} p<0.05$ compared to control lgG. $\mathbf{d}-\mathbf{g}$ The effect of Sp1 on ZnT3 expression. ZnT3 expression level greatly increase in BHK cells overexpressing Sp1 (d Western blot analysis, e RT-PCR analysis). In contrast, ZnT3 expression level decreases in BHK cells transfected with Sp1 siRNA (f Western blot analysis, $\mathbf{g}$ RT-PCR analysis). $\mathrm{n}=4 .{ }^{*} p<0.05$ compared to BHK cells transfected with empty vector 

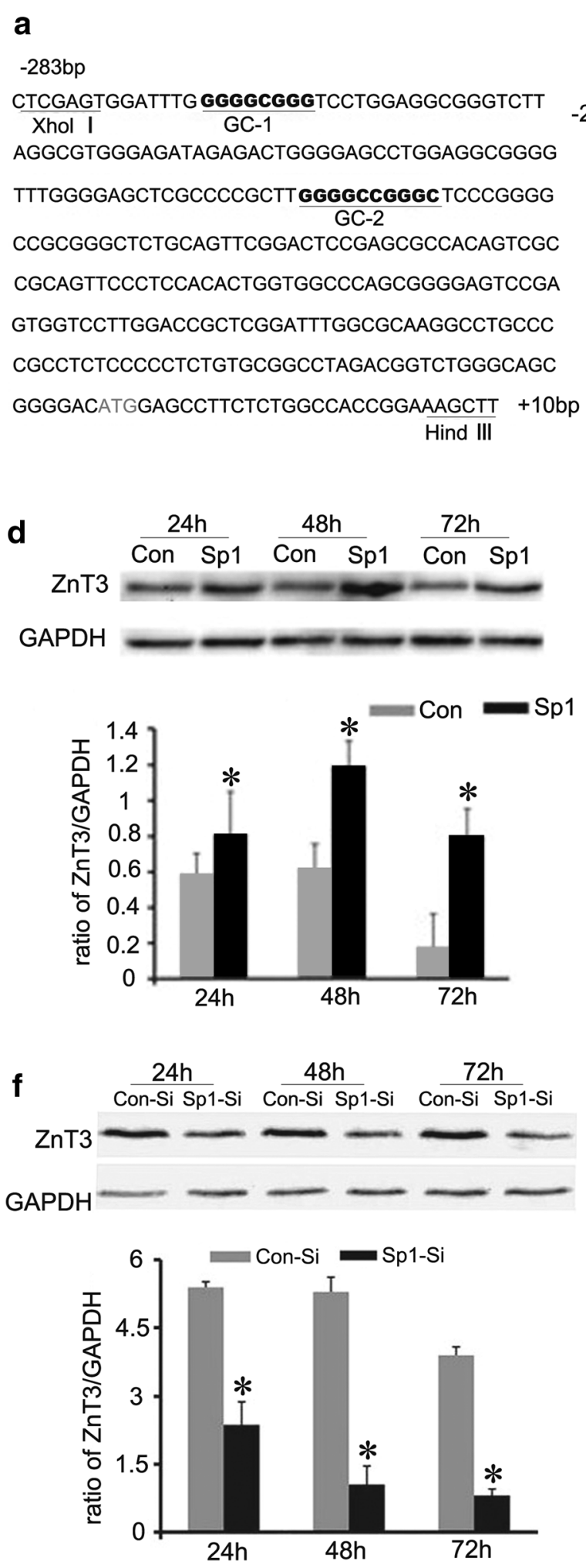
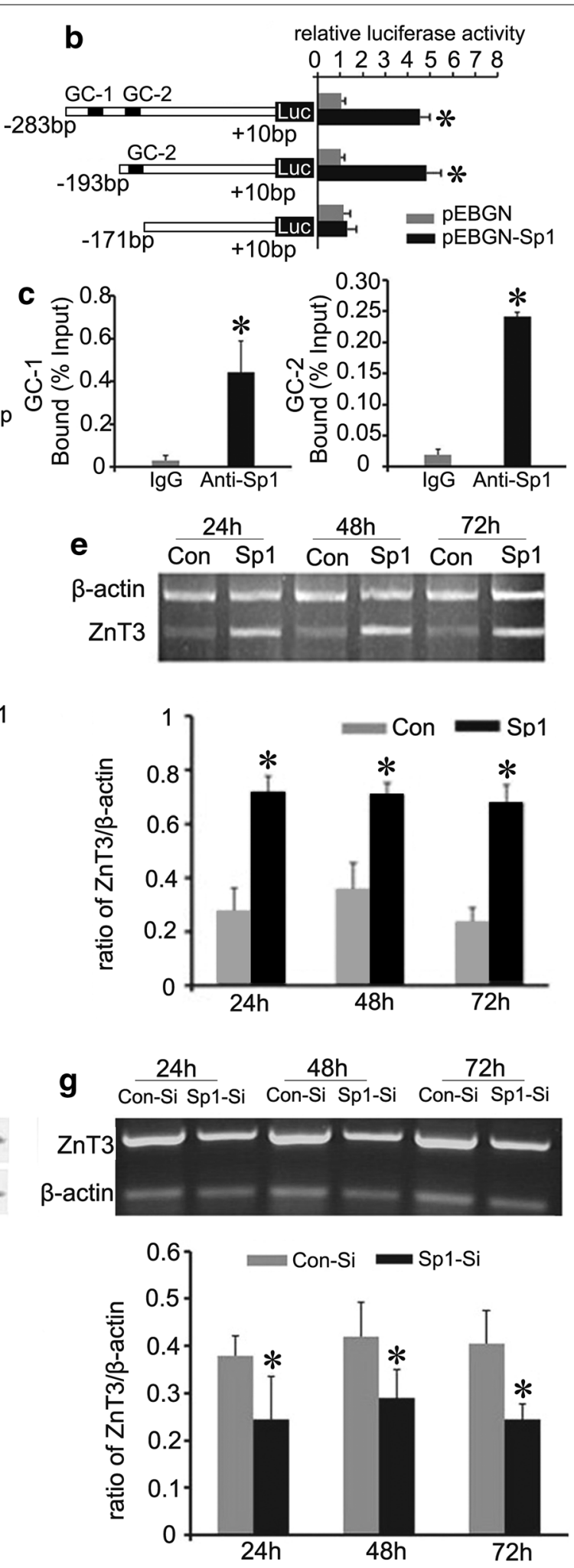

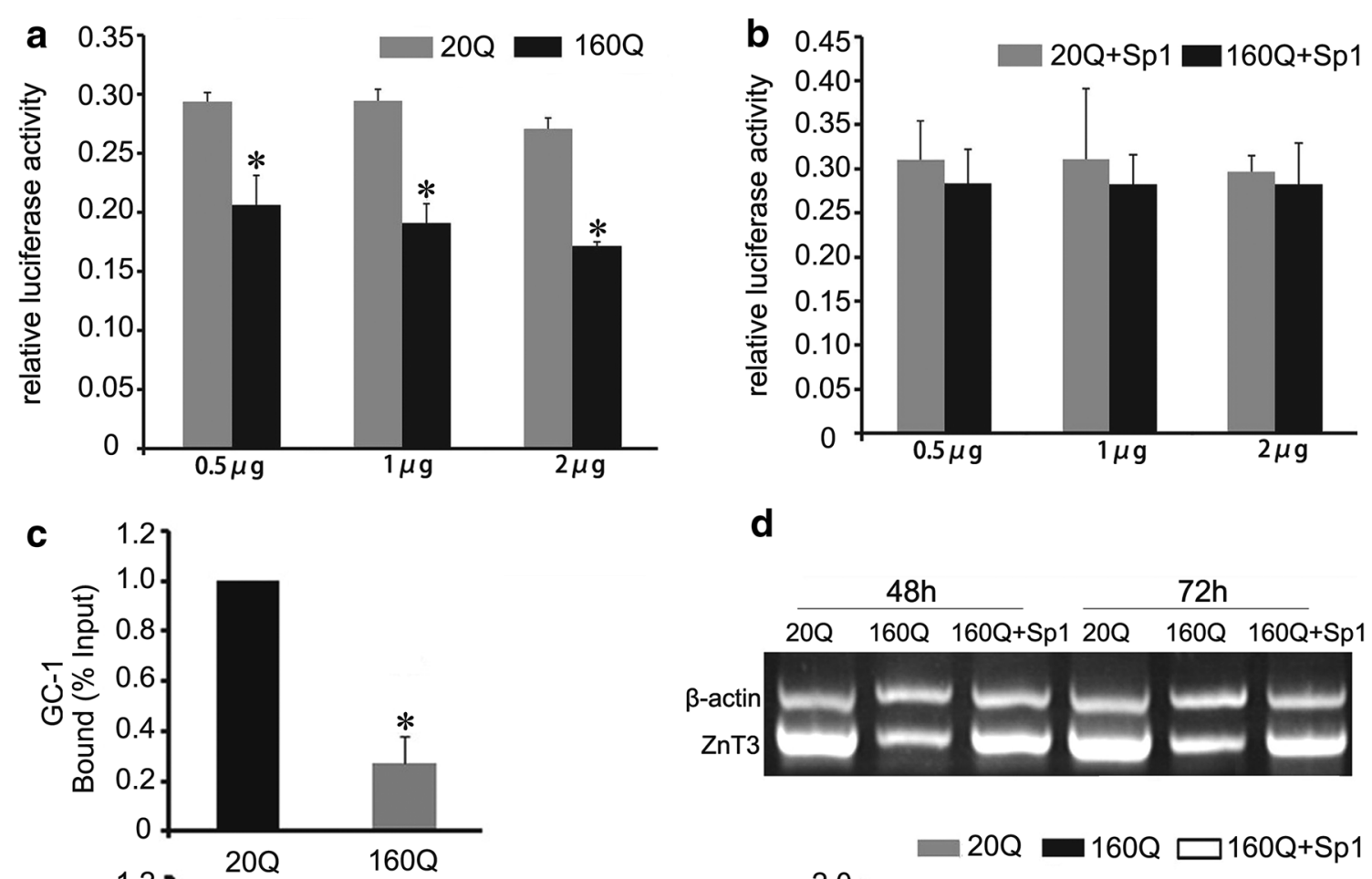

d
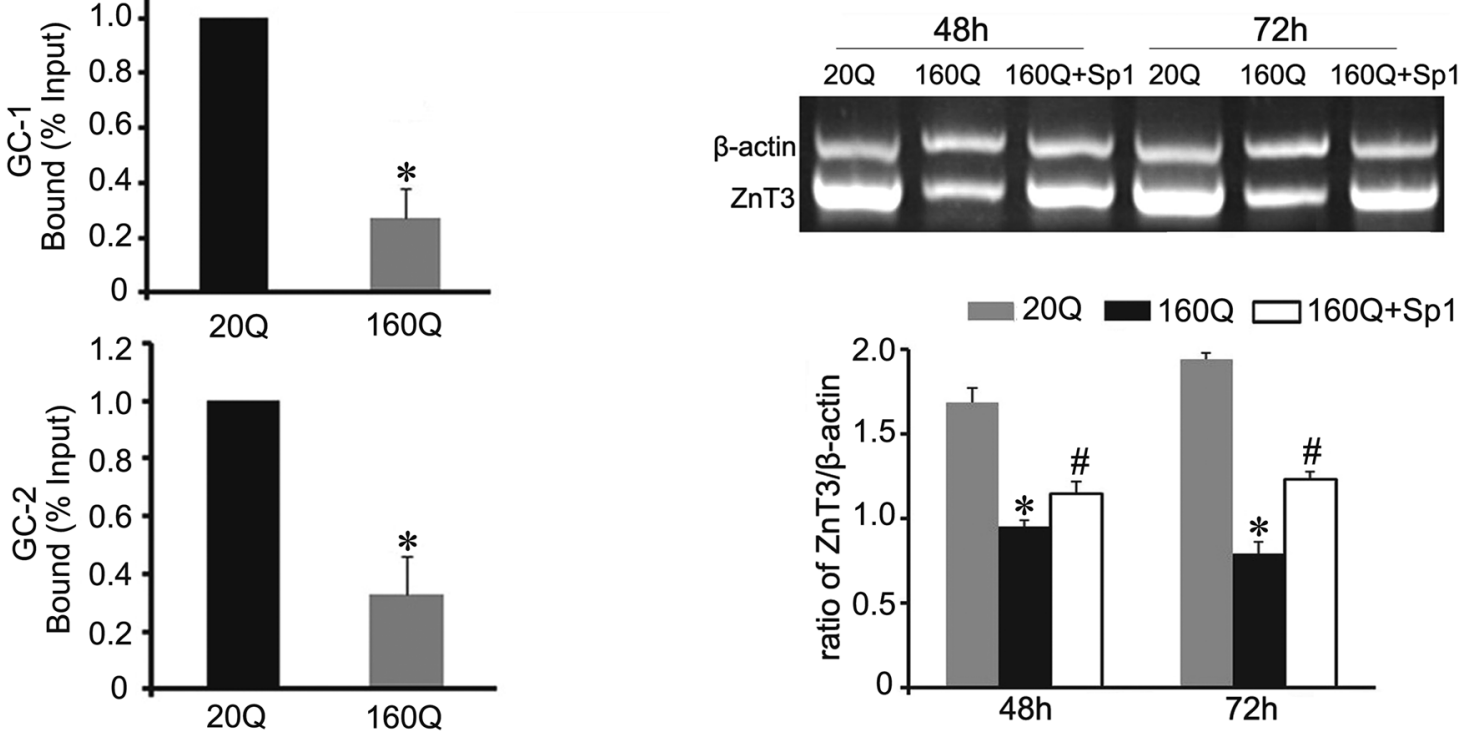

Fig. 6 Mutant huntingtin inhibits the binding of Sp1 to ZnT3 promoter. a Dual-luciferase report gene assay shows that the promoter activity of ZnT3 is down-regulated in BHK cells transfected with different concentrations of $160 \mathrm{Q} H \mathrm{Ht}$ vector. $\mathrm{n}=3 .{ }^{*} p<0.05$ compared to $20 \mathrm{Q}$ cells. $\mathbf{b}$ Dual-luciferase report gene assay shows that Sp1 overexpression up-regulates ZnT3 promoter transcriptional activity in $160 \mathrm{Q}$ BHK cells. $n=3$. c ChIP analysis shows that $\mathrm{mHtt}$ inhibits the binding of Sp1 to ZnT3 promoter containing GC-1 box or GC-2 box. The relative amounts of ZnT3 were normalized to input DNA. $\mathrm{n}=3 .{ }^{*} p<0.05$ compared to $20 \mathrm{Q}$ Htt. $\mathbf{d}$ RT-PCR analysis shows that forced overexpressed Sp1 reverses the suppression of ZnT3 mRNA by mHtt in $160 \mathrm{Q}$ BHK cells. $n=3,{ }^{*} p<0.05$ compared to $20 \mathrm{Q}$ cells. $\# p<0.05$ compared to $160 \mathrm{Q}$ cells

suggesting that down-regulation of ZnT3 does not come from the recruit of $\mathrm{mHtt}$ into aggregates. Additionally, mHtt affects gene expression via altering the activity of transcription factors or via abnormally interacting with them [35, 47, 48]. Two major transcriptional pathways, CRE and Sp1-mediated transcription, have been extensively studied in HD [35]. Increasing findings demonstrate that several genes containing Sp1-binding motifs in their promoters are down-regulated in $\operatorname{HD}[47,48]$. In the present study, one important finding was that $\mathrm{Sp1}$ transactivated $\mathrm{ZnT} 3$ gene by binding the GC boxes in the promoter. We also detected whether mHtt could reduce ZnT3 mRNA level through affecting Sp1 expression.
Interestingly, TG mice displayed an increasing Sp1 expression compared to WT mice, which was consistent with previous reports [49]. This result indicates that inhibition of ZnT3 expression does not result from decreased Sp1 protein.

More importantly, $\mathrm{Sp} 1$ is found to interact with $\mathrm{Htt}$ $[36,50,51]$. mHtt binds to C-terminal region of Sp1, which inhibits the interaction of $\mathrm{Sp} 1$ with its targeting gene promoters $[36,51]$. Here, we confirmed that mHtt inhibits the binding of Sp1 to the GC boxes in the $\mathrm{ZnT3}$ gene promoter so as to reduce ZnT3 expression. Similar mechanism has been verified in previous studies. For example, $\mathrm{Sp} 1$ can bind to the GC boxes in the nerve 
growth factor receptor (NGFR) gene promoter, followed by activating the expression of NGFR. mHtt inhibits the binding of Sp1 to the NGFR promoter to decrease its transcription [36]. As mentioned above, TG mice showed the defective ZnT3 expression at a relatively early stage of this disease. Given that Sp1 disruption also occurs early in human HD pathogenesis, even in postmortem tissues of pre-symptomatic grade [36, 47]. We reasonably infer that mHtt blocks the binding of Sp1 to ZnT3 gene promoter to decrease the expression of ZnT3, thereby disrupting vesicular zinc homeostasis. In order to further confirm this mechanism, we investigated the influence of overexpression of Sp1 on ZnT3 mRNA level in 160Q BHK cells. As expected, overexpression of Sp1 enhanced the transcriptional activity of ZnT3 to up-regulate its mRNA level in our experiments. Thus, overexpression of $\mathrm{Sp} 1$ greatly attenuates inhibition of the binding of Sp1 to ZnT3 promoter by $\mathrm{mHtt}$. Obviously, increasing endogenous Sp1 protein in TG mice might be a reactive result as reduction of binding between $\mathrm{Sp} 1$ and $\mathrm{ZnT} 3$ promoter.

\section{Conclusions}

This work has identified significant reductions in vesicular zinc and the underlying molecular mechanism in HD (Fig. 7). ZnT3 expression is decreased in the brain at the early stage of TG mice, indicating that altered neuronal zinc homestasis is an early event in HD pathogenesis. Sp1 serves as one important transcription factor of ZnT3 to activate its transcription. However, mHtt down-regulates $\mathrm{ZnT} 3$ expression by inhibiting the binding of Sp1 to the $\mathrm{GC}$ boxes in $\mathrm{ZnT3}$ promoter, which further leading to a decrease in the transport of zinc into synaptic vesicles from cytoplasm. The decline in vesiclular zinc induced by $\mathrm{mHtt}$ results in synapse dysfunction and cognitive impairment. Our findings provide novel insights to elucidate the pathogenesis of HD and pave new therapeutic avenues for the treatment of HD.

\section{Methods}

\section{Huntington's disease transgenic mice}

B6C3-Tg (HD82Gln) 81Dbo/J (N171-HD82Q) HD transgenic mice (Jackson Laboratories) express a cDNA encoding a 171 amino acid N-terminal fragment of huntingtin containing 82 CAG (Q) repeats [34]. At the age of 4 weeks, mice were genotyped by polymerase chain reaction (PCR) of tail DNA genotyped according to the Jackson Laboratories protocol to determine hemizygosity for the HD transgene. Wild-type littermates were used as controls. All procedures for animal use were approved by the institutional Animal Care and Committee of Tongji Medical College, Huazhong University of Science and Technology.

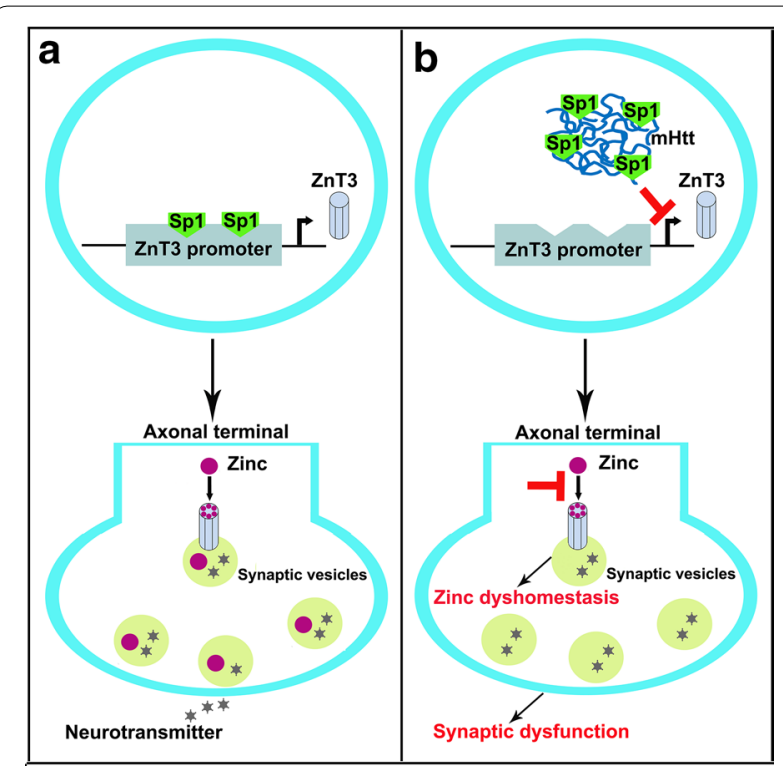

Fig. 7 The mechanism of ZnT3 down-regulation and its effect on vesicular zinc in $\mathrm{HD}$. a Transcription factor Sp1 binds to ZnT3 promoter and up-regulates its expression. Vesicular zinc is dependent on ZnT3 on the membrane of synaptic vesicles in the axonal terminal. $\mathbf{b}$ mHtt inhibits the binding of Sp1 to ZnT3 promoter. Down-regulated ZnT3 expression reduces the transport of zinc into synaptic vesicles. Zinc dyshomestasis contributes to synaptic dysfunction

\section{Plasmids}

For the generation of $\mathrm{ZnT3}$ promoter reporter constructs, pGL3-ZnT3 $(-283-+10)$ vector containing both GC-1 and GC-2 boxes, pGL3-ZnT3 $(-193-+10)$ vector containing GC-2 box and pGL3-ZnT3 $(-171-+10)$ vector without any GC-rich element, the promoter fragments of wild type mice $\mathrm{ZnT} 3$ gene (GenBank accession number 22784) were amplified using the PCR technique and subcloned into pGL-3 basic vector harboring a luciferase reporter gene (Promega). The pEGFP-exon-1 20Q-Htt and pEGFP-exon-1 160Q-Htt plasmids, pEBGN-Sp1 plasmid, nuclear factor $\kappa \mathrm{B}(\mathrm{NF}-\mathrm{\kappa} B$ ) $\mathrm{p} 50$ and NF- $\mathrm{kB}$ (p65) vectors, Wilms' tumor (WT1) gene vectors (WT1 + KTS, WT1-KTS) and pMIC-Sp1 were kindly provided by Xiao-Jiang $\mathrm{Li}$ (USA), Gerald Thiel (Germany), Neil D. Perkins (UK), Holger Scholz (Germany), and Jacqueline Marvel (France), respectively.

\section{Cell culture and transfection}

Baby hamster kidney cells (BHK cells), a specific cell line originally derived from kidney tissue of baby hamster, were cultured as previously described [34]. The cells were planted in the six-well plate. After $24 \mathrm{~h}$, they were transiently transfected with plasmids using Lipofectamine 
TM 2000 (Invitrogen). The cells were replaced with fresh culture medium $6 \mathrm{~h}$ after transfection.

\section{Flame atomic absorption spectrometry (FAAS)}

The 20-week-old N171-82Q mice and age-matched WT mice $(n=3)$ were sacrificed after anesthesia with pentobarbital sodium intraperitoneal injection $(40-45 \mathrm{mg} / \mathrm{kg}$ body weight). After the brain tissues were dissected and weighed, samples were washed and digested in ultrapure nitric acid. All the samples were evaporated to dryness, and were resuspended in $2 \%$ nitric acid. After the resuspending of the samples, the total zinc was detectable by SpectrAA-240FS (VaRIAN).

\section{Autometallography (AMG)}

The 20-week-old N171-82Q mice and age-matched WT mice $(\mathrm{n}=3)$ were anesthetized and perfused transcardially with $4 \%$ paraformaldehyde containing $0.25 \%$ glutaraldehyde after being perfused with $0.3 \%$ sodium sulfide solution.

For light microscopy (LM), the samples were cut into $10 \mu \mathrm{m}$ sections in a cryostat and mounted on glass slides. The sections were placed in Farmer-cleaned jars and immersed in the AMG developer [52]. The jars were placed in a water bath at $26^{\circ} \mathrm{C}$ and shook for $1 \mathrm{~h}$. Then the AMG development was stopped with a $5 \%$ sodium thiosulfate solution for $10 \mathrm{~min}$. The sections were rinsed with water at $38{ }^{\circ} \mathrm{C}$ for $10 \mathrm{~min}$. Images were taken on a Nikon microscope (Digital Camera DXM 1200).

For electron microscopy (EM), the samples after AMG development were fixed with $1 \%$ osmium acid and embedded in epon. Then, the samples were cut into $60 \mathrm{~nm}$ ultrathin sections and were stained with uranyl citrate and lead acetate. Finally, the sections were examined with a transmission electron microscope (FEI Tecnai $G^{2}$ Type 12 ).

\section{Immunohistochemistry}

Immunohistochemical staining of tissues sections was performed as previously described [34]. Briefly, the 20-week-old N171-82Q mice and age-matched WT mice $(\mathrm{n}=3)$ were deeply anesthetized and perfused transcardially with saline, followed by $4 \%$ paraformaldehyde in $0.1 \mathrm{M}$ PB $150 \mathrm{ml}$. The sections were incubated with polyclonal rabbit anti-ZnT3 antibodies (1:100, Proteintech) overnight at $4{ }^{\circ} \mathrm{C}$ followed by biotinylated anti-rabbit IgG (1:200, Vector Labs) for $2 \mathrm{~h}$ and a vidinbiotin complex (1:100, Vector ABC Elite; Vector Labs) for $1 \mathrm{~h}$ at room temperature. Then, the sections were incubated $0.02 \%$ diaminobenzidine (Sigma-Aldrich) and $0.005 \%$ hydogen peroxide in $0.05 \mathrm{M}$ Tris- $\mathrm{HCl}$ buffer for 10 to $15 \mathrm{~min}$. Images were taken on a Nikon microscope (Digital Camera DXM 1200).

\section{Western blot analysis}

Brain tissues from 14-, 18-, and 20-week-old N171-82Q mice and age-matched WT mice $(\mathrm{n}=4$ at each age) and BHK cells at different time after transfection $(n=4$ at each time interval) were lysed in RIPA buffer supplemented with protease and phosphatase inhibitors (Sigma-Aldrich). Protein samples were resolved by SDSPAGE and transferred onto NC membranes. Blots were incubated in primary antibody (1:1000 for ZnT3, 1:1000 for Sp1, 1:10,000 for $\gamma$-tubulin and 1:5000 for GAPDH) overnight at $4{ }^{\circ} \mathrm{C}$ followed by horseradish peroxidaseconjugated secondary antibody for $2 \mathrm{~h}$ at room temperature. The immunoreactive bands were visualized by exposure to an enhanced chemiluminescence (ECL) kit (Pierce Thermo Scientific).

\section{Rt-pcr}

Total RNA from BHK cells, wild type and HD transgenic mice was extracted with Trizol reagent (Invitrogen). ZnT3 and Sp1 mRNA was amplified by reverse-transcription polymerase chain reaction, and $\beta$-actin mRNA was taken as an internal control. The following PCR conditions were used: $94{ }^{\circ} \mathrm{C}$ for $3 \mathrm{~min}$; 30 cycles of denaturing at $94{ }^{\circ} \mathrm{C}$ for $30 \mathrm{~s}$, annealing for $30 \mathrm{~s}$, extension at $72{ }^{\circ} \mathrm{C}$ for $45 \mathrm{~s}$, and a final extension at $72{ }^{\circ} \mathrm{C}$ for $3 \mathrm{~min}$. Photos of the amplified genes were taken after agarose gel (1\%) electrophoresis. The primers and amplification used in the PCRs were listed in the Table 1.

\section{siRNA transfection}

The sense Sp1 siRNA (5'-GGAUGGUUCUGGUCAAAU A-3') and control non-silencing siRNA were produced by RIBOBIO company (China). The BHK cells were grown in Opti-MEM till $60 \%$ confluent. The cells were transfected with siRNA (50 nM) using Lipofectamine TM 2000 (Invitrogen). The cells were harvested at $48 \mathrm{~h}$ after transfection. RT-PCR and Western blot assay were respectively performed to dectect protein and mRNA levels of Sp1.

\section{Dual-luciferase reporter gene assay}

Dual-luciferase reporter gene assays were performed according to the manufacturer's protocol of dual-luciferase reporter assay system (Promega). For the detection of targeting relationship of Sp1 and ZnT3, pEBGN-Sp1 was co-transfected with reporter plasmids pGL3-ZnT3 $(-283-+10)$, pGL3-ZnT3 $(-193-+10)$, or pGL3-ZnT3 $(-171-+10)$, respectively, into BHK cells. pEBGH empty vector was served as a control. For examining the effect of mHtt on ZnT3 transcription activity, different concentration of mHtt vector $(0.5 \mu \mathrm{g}, 1 \mu \mathrm{g}, 2 \mu \mathrm{g})$ was co-transfected with reporter plasmid pGL3-ZnT3 $(-283-+10)$ into BHK cells. 20Q Htt vector was served as a control. Cells were harvested at $48 \mathrm{~h}$ after transfection. Relative luminescence 
Table 1 Primers, amplicon size and annealing temperature of ZnT3, Sp1 and $\beta$-actin for RT-PCR and ChIP-PCR

\begin{tabular}{|c|c|c|c|c|}
\hline \multirow[t]{2}{*}{ Name } & \multicolumn{2}{|l|}{ Primer sequences } & \multirow{2}{*}{$\begin{array}{l}\text { Amplicon } \\
\text { size (bp) }\end{array}$} & \multirow{2}{*}{$\begin{array}{l}\text { Annealing } \\
\text { temperature }\end{array}$} \\
\hline & Forward & Reverse & & \\
\hline$\beta$-actin & GTCGTACCACAGGCATTGTGATGG & GCAATGCCTGGGTACATGGTGG & 492 & $58 / 63^{\circ} \mathrm{C}$ \\
\hline$\beta$-actin & TTTCCAGCCTTCCTTCTTGGGTATG & ATAGAGGTCTTTACGGATGTCAACG & 100 & $58 / 63^{\circ} \mathrm{C}$ \\
\hline ZnT3 & GGAGGTGGTTGGTGGGTATTTAGC & CCATTAGCAGATTGGCACAGACAGC & 317 & $58^{\circ} \mathrm{C}$ \\
\hline Sp1 & AGAACCCACAAGCCCAGACAATC & СTCСTTCTCCACСTGCTGTCTCA & 330 & $63^{\circ} \mathrm{C}$ \\
\hline ZnT3 promoter -338 -232(GC-1) & GTCGTACCACAGGCATTGTGATGG & GCAATGCCTGGGTACATGGTGG & 106 & $60^{\circ} \mathrm{C}$ \\
\hline ZnT3 promoter -253 -112(GC-2) & TTTCCAGCCTTCCTTCTTGGGTATG & ATAGAGGTCTTTACGGATGTCAACG & 141 & $60^{\circ} \mathrm{C}$ \\
\hline
\end{tabular}

units (RLUs) produced by firefly luciferase activity were measured by using LB9507 luminometer. Luciferase activity of pRL-TK Renilla luciferase plasmid was used to determine the background for each luciferase reaction. Luciferase activity $=$ RLU (firefly luciferase)/RLU (Renilla luciferase). All experiments were performed three times, and the mean relative luciferase activity was obtained.

\section{Chromatin immunoprecipitation assay (ChIP)}

ChIP assays were performed using the Magna ChIP A Kit (Millipore) according to the manufacturer's protocol. BHK cells were seeded in $10 \mathrm{~cm}$ dishes. $10 \mu \mathrm{g}$ of preimmune rabbit IgG or anti-Sp1 antibody (ChIP Grade, Abcam) was used for each ChIP reaction. Precipitated DNA was analyzed using a 7500 Real-Time PCR System (Applied Biosystems). The ZnT3 promoter primers used for ChIP-PCR assay are included in Table 1. The amount of amplified DNA was expressed as percent of the input. All ChIP assays were performed three times.

\section{Statistical analysis}

Statistical analyses were carried out using SPSS 17.0 software for one-way ANVOA followed by Student's $t$ test. All values were represented as mean \pm S.D. Differences were considered significant if $p<0.05$.

\section{Supplementary information}

Supplementary information accompanies this paper at https://doi. org/10.1186/s13578-020-00459-3.

Additional file 1: Figure S1. Total zinc level in TG mice brain. Total zinc decreases in the cortex, striatum and hippocampus of the 20-week-old TG mice compared to age-matched WT mice. $\mathrm{n}=3 .{ }^{*} p<0.05$ compared to WT mice. Figure S2. Effect of transcription factors overexpression on ZnT3 expression in WT BHK cells. Overexpression of Sp1 increases ZnT3 protein levels. However, overexpression of other transcription factors, WT1 and NF-kB, does not affect ZnT3 expression. Figure S3. Sp1 expression level in WT BHK cells transfected with Sp1 siRNA. Sp1 siRNA effectively knocks down Sp1 expression in WT BHK cells. $\mathbf{a}, \mathbf{b}$ are Western blots analysis of ZnT3 expression and RT-PCR analysis of ZnT3 mRNA level in BHK cells transfected with different concentrations $(0,5,25,50 \mu \mathrm{g})$ of Sp1 siRNA vectors, respectively. Con-Si: control siRNA; Sp1-Si: Sp1 siRNA

\section{Abbreviations}

HD: Huntington's disease; ZnT3: zinc transporter 3; Htt: Huntingtin; mHtt: Mutant huntingtin; BHK cells: Baby hamster kidney cells; FAAS: Flame atomic absorption spectrometry; AMG: Autometallography; ChIP: Chromatin immunoprecipitation assay.

\section{Acknowledgements}

We thank Xiao-Jiang Li (Emory University School of Medicine, USA), Gerald Thiel (Saarland University of Medical Center, Germany), Neil D. Perkins (Institute for Cell and Molecular Biosciences Medical School, Newcastle upon Tyne, UK), Holger Scholz (Institut für Vegetative Physiologie, Charité-Universitätsmedizin Berlin, Germany), and Jacqueline Marvel (Inserm, U851, Lyon, France) for providing pEBGN-Sp1 plasmid, nuclear factor $\mathrm{KB}$ (NF-KB) p50 and NF-KB (p65) vectors, Wilms tumor 1 (WT1) gene vectors (WT1 + KTS, WT1-KTS), and pMIC-Sp1 vectors, respectively.

\section{Authors' contributions}

$\mathrm{HL}$ and CY conceived the design of the study. LN performed most of experiments. LL performed part of experiments. SY and WW contributed to the cloning of constructs and electron microscopy. CY supervised all experiments, performed the data analysis and wrote the paper with help from LL. All authors read and approved the final manuscript.

\section{Funding}

This work was supported by the National Natural Science Foundation of China [81100947, 81971199] and the Fundamental Research Funds for the Central Universities [HUST2011QN224].

\section{Availability of data and materials}

All data generated or analysed during this study are included in this published article and its Additional files.

\section{Ethics approval and consent to participate}

All procedures for animal use were approved by the institutional Animal Care and Committee of Tongji Medical College, Huazhong University of Science and Technology.

\section{Consent for publication}

Not applicable.

\section{Competing interests}

The authors declare that there is no conflict of interest.

\section{Author details}

${ }^{1}$ Department of Histology and Embryology, Tongji Medical College, Huazhong University of Science and Technology, 13 \# Hangkong Road, Wuhan 430030, People's Republic of China. ${ }^{2}$ School of Biomedical Sciences, LKS Faculty of Medicine, the University of Hong Kong, Hong Kong S.A.R., People's Republic of China. ${ }^{3}$ Hubei Key Laboratory of Embryonic Stem Cell Research, Hubei University of Medicine, Shiyan 442000, People's Republic of China.

Received: 8 July 2020 Accepted: 5 August 2020

Published online: 11 September 2020 


\section{References}

1. Wilson H, De Micco R, Niccolini F, Politis M. Molecular imaging markers to track huntington's disease pathology. Front Neurol. 2017;8:11.

2. Bartlett DM, Domínguez D JF, Reyes A, Zaenker P, Feindel KW, Newton RU, et al. Investigating the relationships between hypothalamic volume and measures of circadian rhythmand habitual sleep in premanifest Huntington's disease. Neurobiol Sleep Circadian Rhythms. 2018:6:1-8.

3. Rüb U, Hentschel M, Stratmann K, Brunt E, Heinsen H, Seidel K, et al. Huntington's disease (HD): degeneration of select nuclei, widespread occurrence of neuronal nuclear and axonal inclusions in the brainstem. Brain Pathol. 2014;24:247-60.

4. Sciacca G, Cicchetti F. Mutant huntingtin protein expression and bloodspinal cord barrier dysfunction in huntingtondisease. Ann Neurol. 2017:82:981-94

5. Gubert C, Renoir T, Hannan AJ. Why Woody got the blues: the neurobiology of depression in Huntington's disease. Neurobiol Dis. 2020;142:104958.

6. Paulsen JS, Miller AC, Hayes T, Shaw E. Cognitive and behavioral changes in Huntington disease before diagnosis. Handb Clin Neurol. 2017:144:69-91.

7. Guo Z, Rudow G, Pletnikova O, Codispoti KE, Orr BA, Crain BJ, et al. Striatal neuronal loss correlates with clinical motor impairment in Huntington's disease. Mov Disord. 2012;27:1379-86.

8. Brito V, Giralt A, Enriquez-Barreto L, Puigdellívol M, Suelves N, ZamoraMoratalla A, et al. Neurotrophin receptor p75(NTR) mediates Huntington's disease-associated synaptic and memory dysfunction. J Clin Invest. 2014:124:4411-28.

9. Kovalenko M, Milnerwood A, Giordano J, St Claire J, Guide JR, Stromberg $M$, et al. HttQ111/+huntington's disease knock-in mice exhibit brain region-specific morphological changes and synaptic dysfunction. J Huntingtons Dis. 2018;7:17-33.

10. Behrens PF, Franz P, Woodman B, Lindenberg KS, Landwehrmeyer GB. Impaired glutamate transport and glutamate-glutamine cycling: downstream effects of the Huntington mutation. Brain. 2002;125:1908-22.

11. Kleiman RJ, Kimmel LH, Bove SE, Lanz TA, Harms JF, Romegialli A, et al. Chronic suppression of phosphodiesterase 10A alters striatal expression of genes responsible for neurotransmitter synthesis, neurotransmission, and signaling pathways implicated in Huntington's disease. J Pharmacol Exp Ther. 2011;336:64-76

12. Milnerwood AJ, Gladding CM, Pouladi MA, Kaufman AM, Hines RM, Boyd $J D$, et al. Early increase in extrasynaptic NMDA receptor signaling and expression contributes to phenotype onset in Huntington's disease mice. Neuron. 2010;65:178-90.

13. Simmons DA, Rex CS, Palmer L, Pandyarajan V, Fedulov V, Gall CM, et al. Up-regulating BDNF with an ampakine rescues synaptic plasticity and memory in Huntington's disease knockin mice. Proc Natl Acad Sci U S A. 2009:106:4906-11.

14. Pancani T, Foster DJ, Moehle MS, Bichell TJ, Bradley E, Bridges TM, et al. Allosteric activation of M4 muscarinic receptors improve behavioral and physiological alterations in early symptomatic YAC 128 mice. Proc Natl Acad Sci U S A. 2015:112:14078-83.

15. Saavedra A, García-Díaz Barriga G, Pérez-Navarro E, Alberch J. Huntington's disease: novel therapeutic perspectives hanging in the balance. Expert Opin Ther Targets. 2018;22:385-99.

16. Okamoto S, Pouladi MA, Talantova M, Yao D, Xia P, Ehrnhoefer DE, et al Balance between synaptic versus extrasynaptic NMDA receptor activity influences inclusions and neurotoxicity of mutant huntingtin. Nat Med. 2009:15:1407-13.

17. Hannan AJ. Synaptopathy, circuitopathy and the computational biology of Huntington's disease. BMC Biol. 2018;16:71.

18. Tyebji S, Hannan AJ. Synaptopathic mechanisms of neurodegeneration and dementia: insights from Huntington's disease. Prog Neurobiol. 2017;153:18-45.

19. Mocchegiani E, Bertoni-Freddari C, Marcellini F, Malavolta M. Brain, aging and neurodegeneration: role of zinc ion availability. Prog Neurobiol. 2005;75:367-90

20. Frederickson CJ, Suh SW, Silva D, Frederickson CJ, Thompson RB. Importance of zinc in the central nervous system: the zinc-containing neuron. J Nutr. 2000;130:1471S-83S

21. Wenzel HJ, Cole TB, Born DE, Schwartzkroin PA, Palmiter RD. Ultrastructural localization of zinc transporter-3 (ZnT-3) to synaptic vesicle membranes within mossy fiber boutons in the hippocampus of mouse and monkey. Proc Natl Acad Sci U S A. 1997;94:12676-81.

22. Khalil R, Levitt JB. Use of synaptic zinc histochemistry to reveal different regions and laminae in the developing and adult brain. J Vis Exp. 2017. https://doi.org/10.3791/56547.

23. Blakemore LJ, Trombley PQ. Zinc as a neuromodulator in the central nervous system with a focus on the olfactory bulb. Front Cell Neurosci. 2017;11:297.

24. Ha HTT, Leal-Ortiz S, Lalwani K, Kiyonaka S, Hamachi I, Mysore SP, et al. Shank and zinc mediate an AMPA receptor subunit switch in developing neurons. Front Mol Neurosci. 2018;11:405.

25. Saito T, Takahashi K, Nakagawa N, Hosokawa T, Kurasaki M, Yamanoshita $\mathrm{O}$, et al. Deficiencies of hippocampal Zn and ZnT3 accelerate brain aging of Rat. Biochem Biophys Res Commun. 2000;279:505-11.

26. Cotrim CA, Jarrott RJ, Martin JL, Drew D. A structural overview of the zinc transporters in the cation diffusion facilitator family. Acta Crystallogr D Struct Biol. 2019;75:357-67.

27. Adlard PA, Parncutt JM, Finkelstein DI, Bush Al. Cognitive loss in zinc transporter-3 knock-out mice: a phenocopy for the synaptic and memory deficits of Alzheimer's disease? J Neurosci. 2010;30:1631-6.

28. McAllister BB, Dyck RH. Zinc transporter 3 (ZnT3) and vesicular zinc in central nervous system function. Neurosci Biobehav Rev. 2017:80:329-50.

29. Sikora J, Kieffer BL, Paoletti P, Ouagazzal AM. Synaptic zinc contributes to motor and cognitive deficits in 6-hydroxydopamine mouse models of Parkinson's disease. Neurobiol Dis. 2020;134:104681.

30. Sensi SL, Granzotto A, Siotto M, Squitti R. Copper and Zinc Dysregulation in Alzheimer's Disease. Trends Pharmacol Sci. 2018;39:1049-63.

31. Kaneko M, Noguchi T, Ikegami S, Sakurai T, Kakita A, Toyoshima Y, et al. Zinc transporters ZnT3 and ZnT6 are downregulated in the spinal cords of patients with sporadic amyotrophic lateral sclerosis. J Neurosci Res. 2015;93:370-9.

32. Squadrone S, Brizio P, Abete MC, Brusco A. Trace elements profile in the blood of Huntington' disease patients. J Trace Elem Med Biol. 2020;57:18-20.

33. Lumsden AL, Henshall TL, Dayan S, Lardelli MT, Richards RI. Huntingtindeficient zebrafish exhibit defects in iron utilization and development. Hum Mol Genet. 2007;16:1905-20.

34. Niu L, Ye C, Sun Y, Peng T, Yang S, Wang W. Mutant huntingtin induces iron overload via up-regulating IRP1 in Huntington's disease. Cell Biosci. 2018;8:41.

35. Sugars KL, Rubinsztein DC. Transcriptional abnormalities in Huntington disease. Trends Genet. 2003:19:233-8.

36. Li SH, Cheng AL, Zhou H, Lam S, Rao M, Li H, et al. Interaction of Huntington disease protein with transcriptional activator Sp1. Mol Cell Biol. 2002;22:1277-87.

37. Takeda A, Tamano H. Insight into cognitive decline from $\mathrm{Zn}^{2+}$ dynamics through extracellular signaling of glutamate and glucocorticoids. Arch Biochem Biophys. 2016:611:93-9.

38. Takeda A, Tamano H. Significance of the degree of synaptic $\mathrm{Zn}^{2+}$ signaling in cognition. Biometals. 2016;29:177-85.

39. Perez-Rosello T, Anderson CT, Schopfer FJ, Zhao Y, Gilad D, Salvatore $\mathrm{SR}$, et al. Synaptic $\mathrm{Zn}^{2+}$ inhibits neurotransmitter release by promoting endocannabinoid synthesis. J Neurosci. 2013:33:9259-72.

40. Anitha M, Nandhu MS, Anju TR, Jes P, Paulose CS. Targeting glutamate mediated excitotoxicity in Huntington's disease: neural progenitors and partial glutamate antagonist-memantine. Med Hypotheses. 2011;76:138-40.

41. Huang SS, He J, Zhao DM, Xu XY, Tan HP, Li H. Effects of mutant huntingtin on mGluR5-mediated dual signaling pathways: implications for therapeutic interventions. Cell Mol Neurobiol. 2010:30:1107-15.

42. Smith R, Klein P, Koc-Schmitz Y, Waldvogel HJ, Faull RL, Brundin P, et al. Loss of SNAP-25 and rabphilin 3a in sensory-motor cortex in Huntington's disease. J Neurochem. 2007;103:115-23.

43. Luthi-Carter R, Apostol BL, Dunah AW, DeJohn MM, Farrell LA, Bates GP, et al. Complex alteration of NMDA receptors in transgenic Huntington's disease mouse brain: analysis of mRNA and protein expression, plasma membrane association, interacting proteins, and phosphorylation. Neurobiol Dis. 2003;14:624-36.

44. Smith-Dijak Al, Sepers MD, Raymond LA. Alterations in synaptic function and plasticity in Huntington disease. J Neurochem. 2019;150:346-65. 
45. Zhu Y, Li C, Tao X, Brazill JM, Park J, Diaz-Perez Z, et al. Nmnat restores neuronal integrity by neutralizing mutant Huntingtin aggregate-induced progressive toxicity. Proc Natl Acad Sci U S A. 2019;116:19165-75.

46. Qin ZH, Wang Y, Sapp E, Cuiffo B, Wanker E, Hayden MR, et al. Huntingtin bodies sequester vesicle-associated proteins by a polyproline-dependent interaction. J Neurosci. 2004;24:269-81.

47. Dunah AW, Jeong H, Griffin A, Kim YM, Standaert DG, Hersch SM, et al. Sp1 and TAFII130 transcriptional activity disrupted in early Huntington's disease. Science. 2002;296:2238-43.

48. Ravache M, Weber C, Mérienne K, Trottier Y. Transcriptional activation of REST by Sp1 in Huntington's disease models. PLoS ONE. 2010:5:e14311.

49. Qiu Z, Norflus F, Singh B, Swindell MK, Buzescu R, Bejarano M. Sp1 is upregulated in cellular and transgenic models of Huntington disease, and its reduction is neuroprotective. J Biol Chem. 2006;281:16672-80.
50. Wang R, Luo Y, Ly PT, Cai F, Zhou W, Zou H. Sp1 regulates human huntingtin gene expression. J Mol Neurosci. 2012;47:311-21.

51. Cornett J, Smith L, Friedman M, Shin JY, Li XJ, Li SH. Context-dependent dysregulation of transcription by mutant huntingtin. J Biol Chem. 2006;281:36198-204.

52. Danscher G, Stoltenberg M, Bruhn M, Sondergaard C, Jensen D. Immersion autometallography: histochemical in situ capturing of zinc ions in catalytic zinc-sulfur nanocrystals. J Histochem Cytochem. 2004;52:1619-25

\section{Publisher's Note}

Springer Nature remains neutral with regard to jurisdictional claims in published maps and institutional affiliations.
Ready to submit your research? Choose BMC and benefit from:

- fast, convenient online submission

- thorough peer review by experienced researchers in your field

- rapid publication on acceptance

- support for research data, including large and complex data types

- gold Open Access which fosters wider collaboration and increased citations

- maximum visibility for your research: over 100M website views per year

At BMC, research is always in progress.

Learn more biomedcentral.com/submissions 